\title{
グリッド型水循環系解析モデルの 多摩川流域への適用 \\ APPLICATION OF A GRID-BASED HYDROLOGICAL CYCLE ANALYSIS MODEL TO TAMA RIVER BASIN
}

\author{
羽田野㻟磨 1 - 高木康行 ${ }^{2}$ - 中嶋規行 ${ }^{3}$ - 中村茂 $2 \cdot$ Srikantha HERATH ${ }^{4}$ \\ Takuma HADANO, Yasuyuki TAKAGI ,Noriyuki NAKASHIMA,Shigeru NAKAMURA and \\ Srikantha HERATH
}

\begin{abstract}
1正会員 工修 日本工営株式会社 河川・水工部（テ330-0801 埼玉県さいたま市土手町1-2JA共済埼玉ビル8階） 2 正会員 工修 日本工営株式会社 総合技術開発部（テ300-1259 茨城県つくば市稲荷原 2304）

3非会員 工修 日本工営株式会社 河川・水工部（テ330-0801 埼玉県さいたま市土手町 1-2JA共済埼玉ビル8階） 4 正会員 工博 国際連合大学（テ150-8925 東京都渋谷区神宮前5-53-70）
\end{abstract}

\begin{abstract}
A grid-based hydrological cycle analysis model, developed and verified in an urbanized small river watershed, is applied to Tama river basin. This model is a physically based distributed one considering not only natural hydrological cycle but also artificial water use. In this paper, a modeling technique is described for the Tama river basin that has $1,240 \mathrm{~km}^{2}$ and a population of about 3.4 million. Then the model calibration and verification are carried out with several river and ground water observation records. The simulated results show relatively good agreement with the observation. Interflow conductivity is found to be an important parameter for river discharge during the flood and its recession period.
\end{abstract}

Key Words : Hydrological cycle, physically based distributed model, Tama river basin

\section{1. はじめに}

流域の都市化に伴う治水・利水・環境上の様々な弊害 に対して, 水の機能を適切でバランスのとれた状態とす る「水循環系の健全化」を目的に, 各種の水施策を総合 化する水マスタープランが検討されている11, 2). 水マス タープラン等の検討では, 地域住民や関連行政部局等の 異なるバックグラウンドを持つ人々が協力して水循環系 の健全化に向けて取り組む必要があり,このためには, 流 域における水循環系の実態や各種施策の効果を定量的か つ分かりやすく説明するためのツールとして水循環系解 析モデルが有効である.

本研究の最終的な目的は, 多摩川流域を対象に水之污 濁負荷の流れを再現可能な解析モデルを構築し, 流域水 循環系の実態把握とそれを踏まえた水循環系健全化施策 の効果を定量的に明らかにすることである. 本論では，そ の第一段階として水量を対象に, 中村ら ${ }^{3)}$ の開発したグ リッド型水循環系解析モデルを多摩川流域に適用し検証 した結果について述べるものである.

\section{2. 対象流域のモデル化}

\section{（1）解析モデルの概要}

本研究で用いる解析モデルは, 中村ら ${ }^{3)}$ が開発したグ リッド型水循環系解析モデルある。このモデル は, Herath・虫明らの研究41, 51, 67,77を参考に, 都市内小河川 である海老川流域 (流域面積27. $1 \mathrm{~km}^{2}$ ) を対象に開発・適
用されたものであり, 河川流量及び地下水位に関して良 好な再現性を有していることが確認されている.このモ デルは, 物理パラメー夕を持つ支配方程式を数值解析す ることで, 地表, 表層土壤, 帯水層及び河道における水の 移動を追跡する分布物理型モデルであるため流域のス ケールや土地利用及び地質構造等の条件が異なっても, 適切な入力条件を設定すれば, 同様の再現性が期待でき る.

グリッド型水循環系解析モデルでは, 流域を図-1のよ うに一定間隔の正方形メッシュの集合として表現し，そ れぞれに図- 2に示す直方体を設定して解析を行う. また, 入力条件として流域の地形, 地質, 降雨, 蒸発散能等の自 然条件に加え, 雑排水量, 下水処理場からの放流, 上水道 漏水量, 下水道浸出水量及び上工水・農業用水の取水量 等の人為的な水の流れを考慮できる. 出力される結果よ り, メッシュ毎の浸透, 蒸発散, 河川への表面·中間·地下 水流出及び帯水層内の地下水流動や, 数百mの間隔で設置 された河道計算断面での時間単位の河川流量といった, 流域水循環系に関する詳細な情報を取得することができ る. 解析モデルは, (1)地表十表層土壌モデル, (2)帯水層モ デル, (3河道モデルから構成され，それぞれに支配方程式 を設定し数值解析することで水の流れを追跡する. 解析 手法の詳細は文献引に示されているため,ここでは多摩川 流域のモデル化を中心に以下に述べる. なお, 解析に用い たメッシュサイズは, 地形条件の再現性と計算時間及び

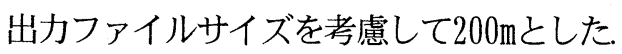




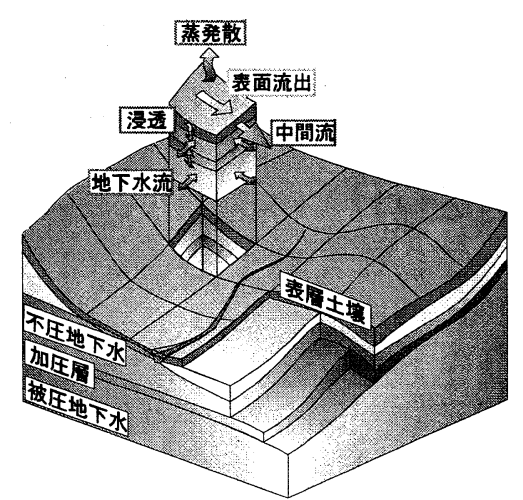

図- 1 流域表現の概念図

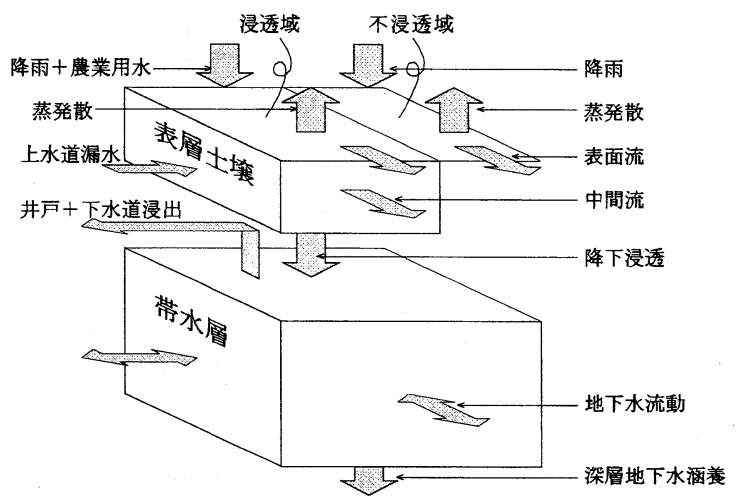

図- 2 メッシュ内の概念図

\section{(2) 対象流域の概要}

多摩川流域は, その源を山梨県塩山市の笠取山 (標高 $1,953 \mathrm{~m})$ に発し, 山梨県, 東京都, 神奈川県を経由して羽田 沖の東京湾に流出する幹線流路延長 $138 \mathrm{~km}$, 流域面積 1, 240 $\mathrm{km}^{2}$ の一級河川である. 図- 3に示すように流域の土 地利用は, 上流域に森林が広く分布し, 中下流域に市街地 が進展している. 流域内の人口は約 340 万人であり, その ほとんどが中下流域の市街地に集中している.

本研究では, 市街化の進展した中下流域の水循環系に 着目し, 解析対象範囲を河口から約 $80 \mathrm{~km}$ 地点の白丸調整 池ダム下流域 (流域面積 $845 \mathrm{~km}^{2}$ ) とした. 白丸調整池ダム より上流からの流出量は, ダム放流量及び発電水量の日 単位の実測值を境界条件として与えた。

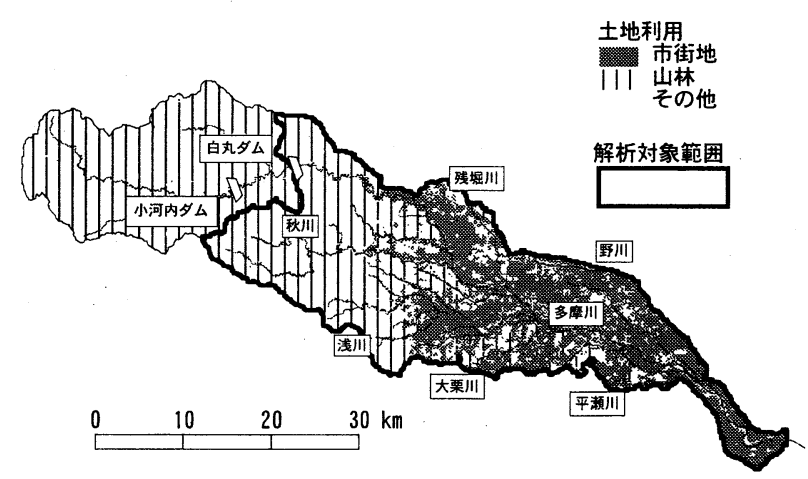

図一 3 解析対象流域とその土地利用

\section{（3）地表十表層土塞モデル}

1メッシュの地表面を不浸透域と浸透域に区分し, 以下 のモデル化を行う.

\section{a) 不浸透域モデル}

不浸透域モデルでは, 降雨と蒸発散能を入力として, 一 定の窪地貯留能 ( $2 \mathrm{~mm}$ と設定) をもつ仮想池の水収支計算 より蒸発散量と表面流となる余唾降雨が計算される.

この際, 計算メッシュ内に占める不浸透域の割合（不 浸透面積率）を設定する必要がある. 不浸透面積率は, 洪 水時のピーク流量や浸透量の計算結果に大きく影響を及 ぼす重要なパラメータである. 土地利用に関する数值情 報が利用可能であることを考えると, 土地利用地目毎の 不浸透面積率の值を与えることで流域全体の不浸透面積 率の分布を設定することが可能となる.

ここでは, 文献 ${ }^{8)}$ の方法を参考に, できる限り客観的な 地目毎の不浸透面積率の算定を行う. まず, 流域を比較的 市街地化の進展した下流域・中流域と森林が主要な土地 利用である上流域に区分し, 表- 1に示すサンプリング領 域を設定する. 次にこの領域で $1 / 25,000$ の地形図からサ ンプリングした不浸透域と, 土地利用に関する数值情報 を重ね合わせて地目毎の不浸透面積率を設定した. なお, 下流域では鶴見川流域でサンプリングされた值”を用い た. 表- 2に上記の方法で求めた土地利用地目毎の不浸透 面積率を示す. 道路用地の不浸透面積率が $0.3 〜 0.6$ とな るのは土地利用メッシュ全域が必ずしも道路とは限らな いためである. また, 下流域と中流域で比較した場合, 密 集低層住宅 (下流域0.50, 中流域0.37) と道路用地 (下流域 0.51, 中流域0.61) に違いが見られ，その他について概ね 同程度の值となった.この違いは，下流域では住宅密集度 が高いこと, 中流域では幹線道路が多く土地利用メッ シュ内に占める不浸透域が大きいことに起因すると考え られる.

\begin{tabular}{|c|c|c|}
\hline & サンプリング領域 & 重ね合わせる土地利用情報 \\
\hline 下流域 & 鶴見川流域の約南半分の領域 & 紐密数値情報 (1994年) \\
\hline 中流域 & $1 \mathrm{~km}^{2}$ 四方の領域を無作為に10籄所抽出 & 同上 \\
\hline 上流域 & 同上 & 1/10細分区画土地利用 \\
\hline
\end{tabular}

表- 2 土地利用地目毎の不浸透面積率

\begin{tabular}{|l|c|c|l|l|}
\hline \multicolumn{1}{|c|}{ 細密数值情報 } & 下流域 & 中流域 & 1/10細分区画土地利用 & 上流域 \\
\hline \hline 山林·荒地等 & 0.07 & 0.01 & 田 & 0.13 \\
\hline 田 & 0.10 & 0.12 & 畑 & 0.10 \\
\hline 畑・その他農地 & 0.14 & 0.14 & 果樹園 & 0.06 \\
\hline 造成中地 & 0.12 & 0.08 & その他の樹木畑 & 0.06 \\
\hline 空き地 & 0.25 & 0.26 & 森林 & 0.01 \\
\hline 工業用地 & 0.37 & 0.38 & 荒地 & 0.00 \\
\hline 一般低層住宅 & 0.38 & 0.35 & 建物用地 $A$ & 0.43 \\
\hline 密集低層住宅 & 0.50 & 0.37 & 建物用地 $B$ & 0.20 \\
\hline 中・高層住宅 & 0.33 & 0.39 & 幹線交通用地 & 0.32 \\
\hline 商業・業務用地 & 0.42 & 0.45 & その他用地 & 0.22 \\
\hline 道路用地 & 0.51 & 0.61 & 湖沼 & 0.00 \\
\hline 公園・緑地等 & 0.13 & 0.16 & 河川A & 0.20 \\
\hline その他の公共・公益施設 & 0.21 & 0.20 & 河川B & - \\
\hline 河川・湖沼等 & 0.05 & 0.03 & 海浜 & - \\
\hline その他 & 0.17 & 0.38 & 海水域 & - \\
\hline
\end{tabular}

\section{b) 浸透域+表層土塞モデル}

浸透域モデルは, 地表面の仮想池と地表面下 $2 \mathrm{~m}$ までと 仮定した不飽和土壌により構成され, 降雨, 蒸発散能及び 
上水道漏水を入力として, 蒸発散, 浸潤, 復帰流, 余剩降雨, 降下浸透及び中間流が計算される. 不飽和土㙵内の水分 移動の解析には, 鈶直一次元のRichards 式に中間流, 蒸 発散, 上水道漏水を表す項を加えた式 (1) を適用する゙).

$$
\begin{aligned}
C(\psi) \frac{\partial \psi}{\partial t} & =\frac{\partial}{\partial z}\left\{K(\psi) \frac{\partial \psi}{\partial z}-K(\psi)\right\} \\
& +\frac{K_{I}(\psi)_{s}-I_{\text {in }}}{\Delta x}+W s+E
\end{aligned}
$$

ここに, $\psi$ : 土壤水圧 $[m], z$ : 鉛直方向の座標軸 (鉛 直上向きを正),$\Delta x$ : 流下方向のメッシュ長 $(=200 \mathrm{~m}), C(\psi)=\partial \theta / \partial \psi$ であり比水分容量を表す $[1 / \mathrm{m}], \theta$ : 体積含水率, $K(\psi)$ : 鉛直不飽和透水係数 $[\mathrm{m} / \mathrm{s}], K_{I}(\psi)$ : 側方不飽和透水係数 $[\mathrm{m} / \mathrm{s}], I_{i n}$ : 上流 メッシュから流入する鉛直方向単位長さ当たりの中間流 $[\mathrm{m} / \mathrm{s}], s$ : 地表面勾配, $E, W s$ : 蒸発及び上水道漏水に よる体積含水率変化 $[1 / \mathrm{s}]$ である. 式 (1) は，解析領域 $2 \mathrm{~m} の$ 土壤を鉛直方向に4等分し陽差分法で数值解析する.

不飽和流れの特性は文献》を参考にして, 式 (2) の Harvercamp et al. (1977) ${ }^{9)}$ の水分特性曲線と, 式 (3) の Mualem $(1978)^{100}$ の不飽和透水係数〜吸引圧の関係式を採 用する.

$$
\begin{gathered}
\theta=\frac{\alpha\left(\theta_{0}-\theta_{r}\right)}{\alpha+\{\ln (\varphi)\}^{\beta}}+\theta_{r} \\
K=K_{0}\left(\frac{\theta-\theta_{r}}{\theta_{0}-\theta_{r}}\right)^{n} \quad K_{I}=K_{I 0}\left(\frac{\theta-\theta_{r}}{\theta_{0}-\theta_{r}}\right)^{n}
\end{gathered}
$$

ここに, $\theta$ : 体積含水率 $\left[\mathrm{cm}^{3} / \mathrm{cm}^{3}\right], \theta_{0}$ : 飽和水分量 $\left[\mathrm{cm}^{3} / \mathrm{cm}^{3}\right], \theta_{r}$ : 残留水分量 $\left[\mathrm{cm}^{3} / \mathrm{cm}^{3}\right], \varphi$ : 吸引圧 $\left[\mathrm{cmH}_{2} 0\right], \alpha, \beta$ : 定数, $K_{0}$ : 鉛直方向の飽和透水係数 $[\mathrm{cm} / \mathrm{s}], K_{I 0}$ : 側方飽和透水係数 $[\mathrm{cm} / \mathrm{s}], n$ : 定数である.

式 (2)，(3) 中のパラメー夕は，対象流域の表層地質分布 及び土地利用から以下の方法で設定する.

多摩川流域の表層地質は, 図- 4に示すように, 中下流 域の台地部にローム層が広く分布しており, 一部に上総 層が露頭している. また, 河道周辺に沖積層が分布し, 上 流部の山地には基盤岩が広く分布する. 流域の土地利用 から上流域の基盤岩上には森林土壤が存在すると判断さ れる.この表層地質分布を解析メッシュと重ね合わせ メッシュ毎の表層地質を区分した.

不飽和浸透流計算に用いる鉛直飽和透水係数は, 地質 毎の飽和透水係数を同定対象として式 (4)により設定し た

$$
K_{0}=m \times K_{0}^{\prime}
$$

ここに, $K_{0}^{\prime}$ :地質毎の飽和透水係数（同定対象）, $m$ : 村井ほかの研究成果 ${ }^{11}$ を参考に設定した土地被覆状況に

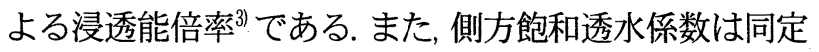
対象とし, その他のパラメー夕は他流域における関東 ローム層を対象とした試験結果を参考 ${ }^{12}$ に設定した.

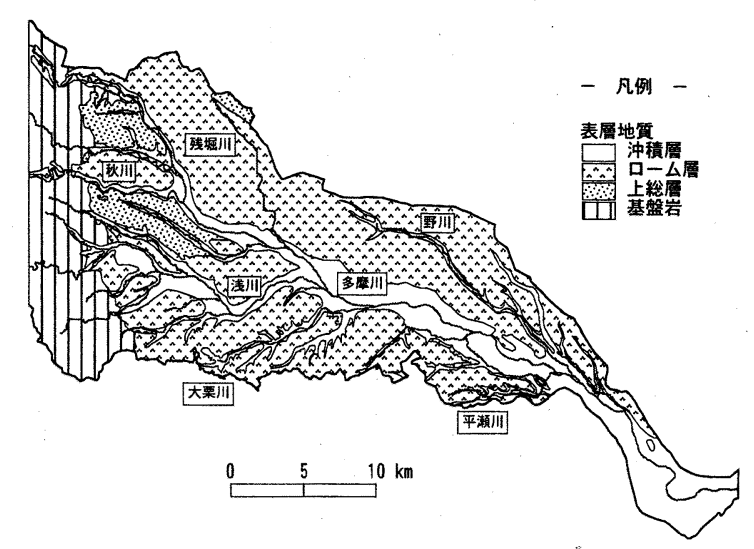

\section{c) 表面流の追跡}

図- 4 多摩川流域の表層地質

表面流の追跡にはKinematic Wave Modelを適用し, 等 価粗度は,メッシュ内の代表的な土地利用から決定した。 等価粗度の值は, 流域内で下水道整備が概ね完了してい ることから市街地で0.005とし，山林，畑地，水田ではそれ ぞれ0. 7, 0.3, 2. $0^{13)}$ とした.

表面流及び中間流の流下経路となる落水線は, 解析 メッシュ内の流下方向を東西南北の 4 方向として, メッ シュ標高から最急勾配で決定し, 上流端メッシュから河 道を有するメッシュまでをこの流下方向を連結して作成 した ${ }^{14}$. 浅川流域における落水線の作成例を図-5に示す.

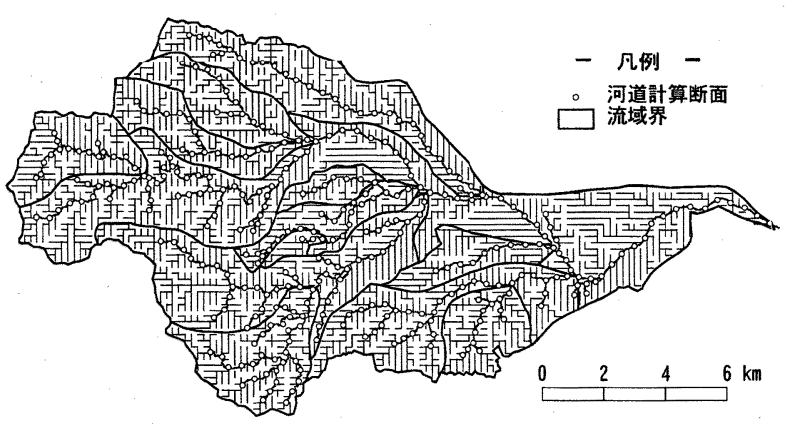

図- 5 落水線の作成例 (浅川流域)

\section{（4）帯水層モデル}

山地を除く多摩川流域には, 表層に厚さ数十mのローム 層及び沖積層が分布し, その下位に上総層が数百mの厚さ で堆積している. また, 多摩川左岸の下流部にはローム層 と上総層の間に下総層が存在する. 地下水は, ローム層と 沖積層内の不圧地下水と下総層・上総層内の被圧地下水 に区分できる. 上総層内の地下水ポテンシャルは北東方 向 (右岸から左岸方向) に向かって傾斜していることが分 かっており, 概略の水収支計算より, 数 $\mathrm{m}^{3} / \mathrm{s}$ 規模の地下水 が, 中下流域左岸側の流域界から流出していると推算さ れている.

河川流量に着目した解析では, 不圧地下水位の再現の みで十分な場合もあるが, 上総層から流域外への地下水 流出の実態を踏まえ, 第一層をローム・沖積層, 第二層を 下総層, 第三層を上総層とする帯水層構造 (図- 6) を設定 し, 被圧地下水の流動まで考慮できる帯水層モデルの構 
築を試みる. なお, 上流域の森林土壌の下位に分布する基 盤岩は不透水層として取り扱った.

帯水層モデルでは, 1つの帯水層内における地下水の流 動を式(5) を支配方程式として解析する.

$S \frac{\partial h_{g}}{\partial t}=\frac{\partial}{\partial x}\left(T \frac{\partial h_{g}}{\partial x}\right)+\frac{\partial}{\partial y}\left(T \frac{\partial h_{g}}{\partial y}\right)+\frac{k^{\prime}}{b^{\prime}}\left(H-h_{g}\right)-Q_{d}$

ここに, $T$ : 透水量係数 $\left[\mathrm{m}^{2} / \mathrm{s}\right], S$ : 貯留量係数, $Q_{d}$ : 鈶直方向の流量条件（浸漏・涵養, 降下浸透, 井戸揚水な ぞ） $[\mathrm{m} / \mathrm{s}], h_{g}$ : 地下水ピエゾ水頭 $[\mathrm{m}], H$ ：上又は下層 の水頭 $[\mathrm{m}], \mathrm{k}^{\prime}$ : 他層との間の難透水層の透水係数 $[\mathrm{m} / \mathrm{s}], \mathrm{b}^{\prime}$ : 同層厚 $[\mathrm{m}]$ である. 透水係数と貯留係数は, 帯 水層の地質毎に再現計算により同定する. 地下水解析の 境界条件は, 既往の調査結果を踏まえ, 多摩川左岸中下流 部の被圧地下水流出境界及び河口部で水位固定, その他 の境界で水平方向の流動をゼロと設定した.

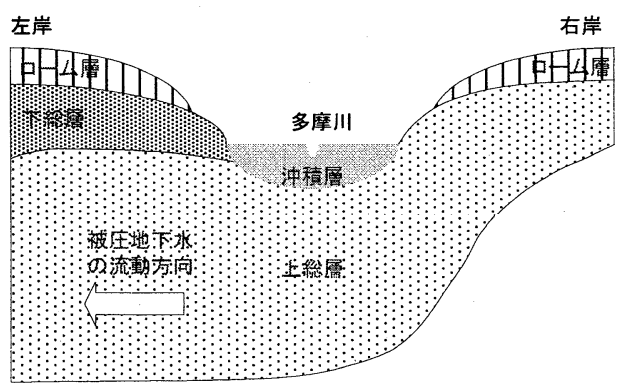

図- 6 多摩川流域における帯水層構造の概念図

また, 河川と帯水層間の水分移動はMcDonald ・ Harbaugh (1988) ${ }^{15)}$ を参考にして式（6）のようにメッ シュ毎の河川水位と地下水位との相互関係により計算す る.

$$
Q_{d r}=\left\{\begin{array}{cl}
k_{b e d} A_{b e d} & ; h_{g} \leq H_{r i v} \\
k_{b e d} \frac{h_{g}-H_{r i v}}{b_{b e d}} A_{b e d} & ; h_{g}>H_{r i v}
\end{array}\right.
$$

ここに, $Q_{d r}$ : 河川への浸漏又は河川からの涵養 $\left[\mathrm{m}^{3} / \mathrm{s}\right], k_{b e d}$ : 河床材料飽和透水係数 $[\mathrm{m} / \mathrm{s}], A_{b e d}:$ 浸潤面 積 $\left[\mathrm{m}^{2}\right], b_{b e d}$ : 河床材料厚さ $[\mathrm{m}], H_{r i v}$ : 河川水位 $[\mathrm{m}]$ であ り, $h_{g}>H_{r i v}$ の場合に地下水流出が生じる. 河床材料の飽 和透水係数は同定対象とする.

\section{（5）河道モデル}

河川の流れ解析にはKinematic Wave Modelを適用し, 計算断面間隔は約 $500 \mathrm{~m}$, Manningの粗度係数は各河川の河 道計画資料等を参考に $\mathrm{n}=0.03$ とした. 河道モデルでは, 地 表面＋表層土壌モデルで求めた地表面流出と中間流出, 帯水層モデルで求めた地下水流出, 下水処理場からの放 流水量及び雑排水を横流入として与え, 上工水と農業用 水の取水量を横流出として与える.

河川へ流入・流出成分の内, 多摩川本川では下水処理 場からの放流水量と取水量が河川流量に与える影響が大
きい. 下水処理場は, 白丸ダムより下流で支川への放流を 含め 10 箇所存在し, 合計の放流量は $5 \sim 10 \mathrm{~m}^{3} / \mathrm{s}$ 程度である. また, 多摩川では河川水が高度に利用されており, 多摩川 本川には, 上工水・農水を合わて数十 $\mathrm{m}^{3} / \mathrm{s}$ の水利権量が 設定されている. これらは多摩川本川の低水流量と同程 度のオーダーである. 取排水量の設定は解析精度を大き く左右するため, ここでは，上工水の取水と処理場放流量 について日単位の実測値を設定した. また, 農業用水につ いては, 代表的な取水地点で取水量の実測值が取得でき たため,この実測值から灌溉面積当たりの取水量を推定 し，これに取水地点毎の灌溉面積を乗じることで, 全取水 地点の取水量を設定した.

\section{（6） その他入力条件}

上記以外の入力条件は文献 ${ }^{22}$ を参考に表- 3 に従って 設定した.

表- 3 その他入力条件の設定方法

\begin{tabular}{|c|c|}
\hline 条件 & 設定方法 \\
\hline 降雨 & $\begin{array}{l}\text { 地上雨量計 (56個所) の時間雨量を与える. 雨量計の代表範囲は } \\
\text { ティーセン法により設定 }\end{array}$ \\
\hline 蒸発散能 & $\begin{array}{l}\text { 気象観測所 (7個所) の気温データからハーモン式を用いて日毎に与 } \\
\text { える.代表範囲はティーセン法により設定. }\end{array}$ \\
\hline 人口分布 & $\begin{array}{l}\text { 三次メッシュ毎の人口(平成7年国勢調査)を,土地利用 (中下流域: } \\
\text { 細密数値情報1994, 上流域: } 1 / 10 \text { 細分区画土地利用 } 1989) \text { 上の可住区 } \\
\text { 域に配,分. }\end{array}$ \\
\hline 雑排水量 & $\begin{array}{l}\text { 下水道未整備地域で生じる污水の河川流出. 下水道未整備区域の } \\
\text { メッシュに水量原単位を割り当て. }\end{array}$ \\
\hline 地下水用水 & $\begin{array}{l}\text { 市区町村ごとの年平均地下水揚水量を人口分布に従って解析メッ } \\
\text { シュに割り当て. }\end{array}$ \\
\hline 上水道漏水 & $\begin{array}{l}\text { 上水道から表層土壌中への漏水 市区町村ごとの無効水量を人口分 } \\
\text { 布に従って解析メッシュ割り当て. }\end{array}$ \\
\hline 下水道浸出 & 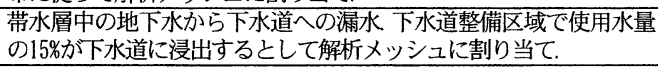 \\
\hline
\end{tabular}

\section{3. 再現計算}

\section{(1) モデルパラメータの同定}

図-7に示す検証地点での河川流量と地下水位の連続 観測結果を再現対象として, モデルパラメータの同定結 果を表- 4に示す.ローム層の透水係数は $1 \times 10^{-3} \mathrm{~cm} / \mathrm{s}$ とな り, 隣接する鶴見川流域での現地試験結果 ${ }^{1)}\left(1 \times 10^{-3} \sim 3\right.$ $\left.\times 10^{-3} \mathrm{~cm} / \mathrm{s}\right)$ とほぼ一致した. また, 上総層の透水係数は, 一般的な值と同オーダーの同定值を得ることができたが, 今後, 被圧地下水の平面的な流動を踏まえて精査してい く必要があると考えられる.

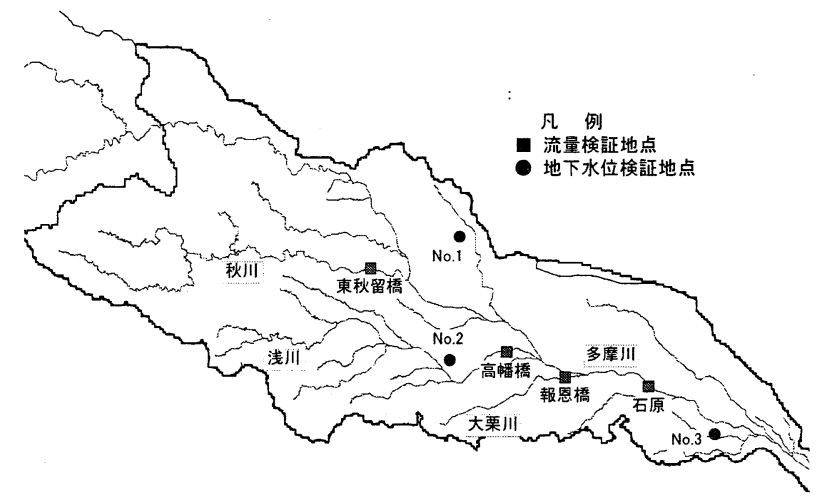

図- 7 河川流量及び地下水位の検証地点 
表- 4 モデルパラメータの同定結果

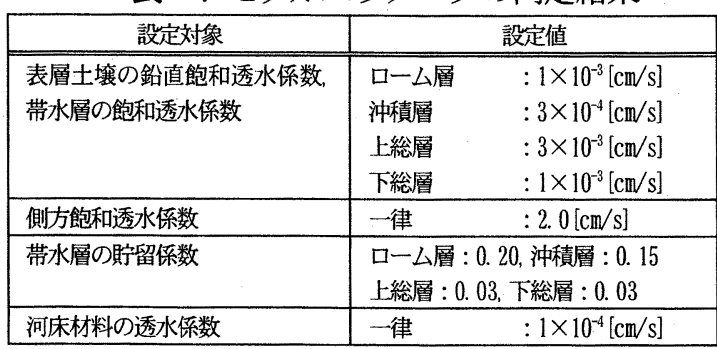

表層土壌からの中間流出を規定する側方飽和透水俰数 $K_{10}$ は, $2 \mathrm{~cm} / \mathrm{s}$ となり鈶直方向のそれと比べて $10^{3}$ オ一 ダーも大きな値となった.これは, 土壌内のパイプ流の影 響を反映したものと考えられる. 地下水深度の地域的な 分布にもよるが, $K_{I 0}$ は, そのオーダーから河川流量の再 現性に及ぼす影響が大きいと考えられる. 図- 8は， $K_{I 0}$ の值を鉛直飽和透水係数と同オーダーの值である $1 \times 10^{-3}$, その 100 倍の $1 . \times 10^{-1}$ 及び同定值である $2 \mathrm{~cm} / \mathrm{s}$ と変化させ, 出水時とその迫減部における再現性の違いを示したもの である.

$K_{I 0}=2 \mathrm{~cm} / \mathrm{s}$ とした場合, 計算値は観測値を概ね良好に 再現している.一方, $K_{10}=1 \times 10^{-3} \mathrm{~cm} / \mathrm{s}$ とした場合, 表層土 㙋からの中間流出が減少するため, 飽和した一部の土壇 からの表面流出が卓越し, ピーク流量が過大に評価され るとともに, 莪減部では, 中間流の減少から河川流量が過 小に評価されている. また, $K_{t 0}=1 \times 10^{-1} \mathrm{~cm} / \mathrm{s}$ とした場合 には, 出水時の中間流出が減少するが, $K_{I 0}=1 \times 10^{-3} \mathrm{~cm} / \mathrm{s}$ のように表面流が卓越する状況に至らず, 出水時のピー ク流量及び流出ボリュームともに過小に評価されている. 莪減部では，出水時において表層土壌内に貯留された水 分が中間流として緩やかに流出することで, $9 / 24$ を境に 河川流量が過大に評価されている，なお, 計算值では, ピーク流量付近で扁平化する観測值のハイドログラフが 再現されていない.これは, 河道にKinematic wave model を適用したため多摩川本川等における貯留効果を十分に 再現できなかったことに起因すると考えられる.

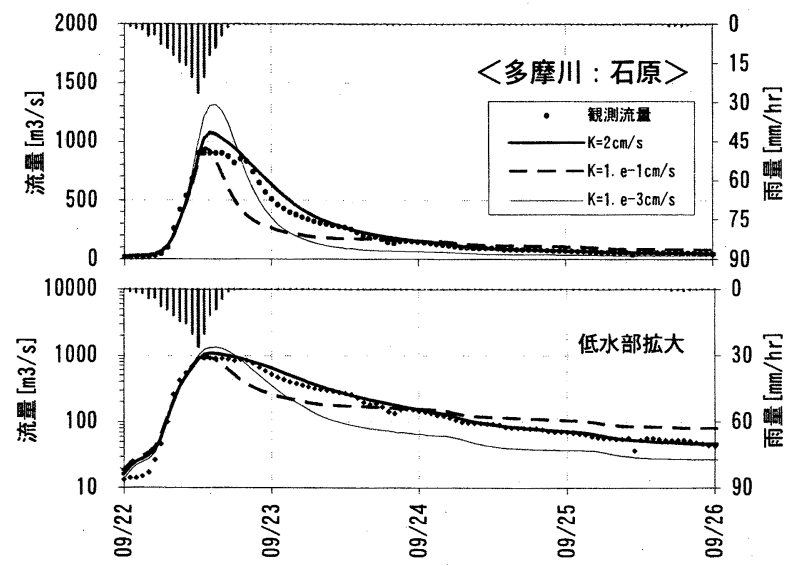

図-8 側方飽和透水係数が河川流量に与える影響

\section{（2）河川流量及び地下水位の再現性}

同定したパラメー夕を用いて再現計算を行い, 検証地 点で河川の日流量及び地下水位の観測值と計算値を比較 した結果を図- 9, 図- 10にそれぞれ示す.また, 河川流量 については, 計算値と観測值の相対誤差の平均について 表-5に併せて示す.

表-5を見る限り, 河川流量に関しては, この種の解析 事例 ${ }^{12)}$ と比較して十分な再現精度が得られたと考える。 しかし, 図-8のハイドログラフの比較から, 市街地から の流出の影響が大きい石原, 高幡橋及び報恩橋では比較 的良好な再現結果を得ることができたのに対し，森林域 が広く分布する秋川流域 東秋留橋では, 計算流量が八イ ドログラフの莪減部を過小に, 出水時の流量を過大に評 価していることが分かる.この地点の再現性を向上させ るためには, 森林土壌からの早い中間流出のモデル化, 土 袞厚さの地域分布の考慮, 森林の影響を考慮した蒸発散 能の設定が必要と考えられる.

表- 5 観測流量と計算流量の相対誤差の平均

\begin{tabular}{|l|l|c|}
\hline \multicolumn{2}{|c|}{ 検証地点 } & $R$ \\
\hline \hline 多摩川 & 石原 & 0.19 \\
\hline 秋川 & 東秋留橋 & 0.26 \\
\hline 浅川 & 高幡橋 & 0.14 \\
\hline 大栗川 & 報恩橋 & 0.24 \\
\hline
\end{tabular}

$R=\frac{1}{n} \sum_{r}^{n} \frac{\left|Q_{o b s}(t)-Q_{\text {cal }}(t)\right|}{Q_{\text {obs }}(t)}$ $R:$ 相対誤差の平均 $Q_{o b s}(t):$ 時刻 $t$ の観測流量 $Q_{c a t}(t):$ 時刻 $t$ の計算流量 $n:$ 比較するデー夕数
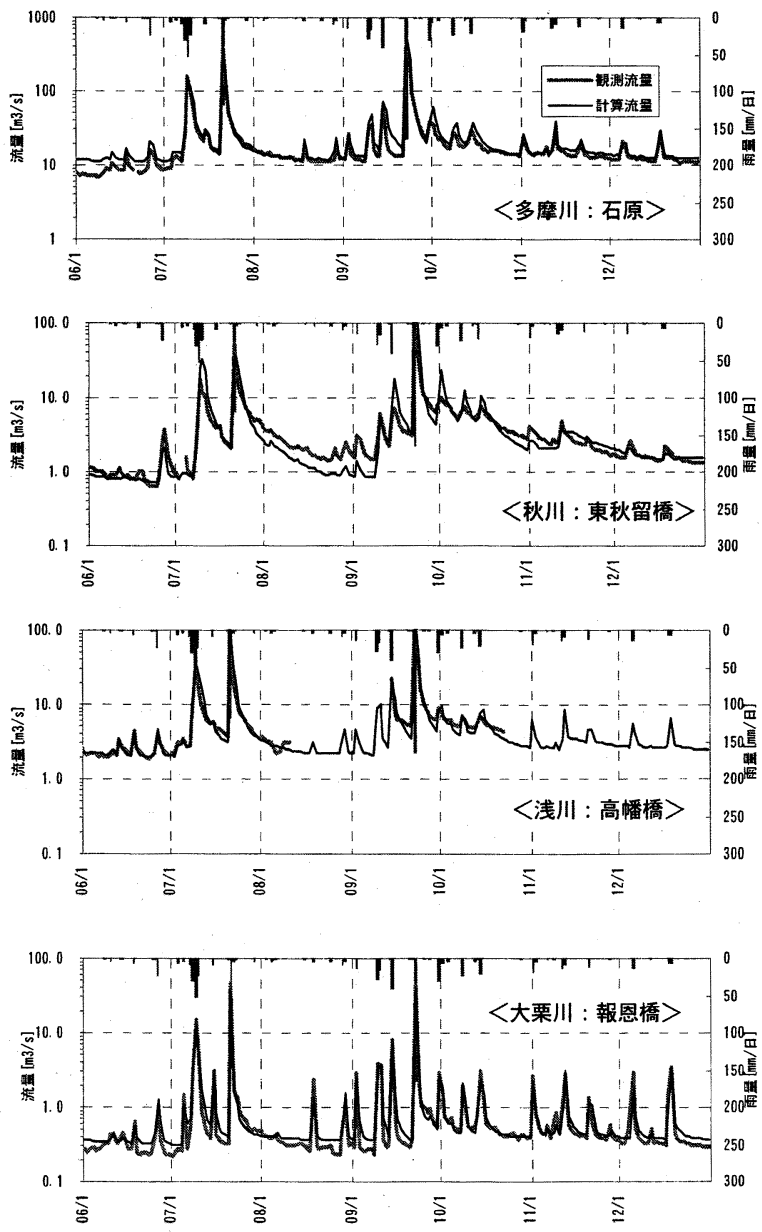

図- 9 河川流量の再現計算結果（日流量） 
地下水位については, 図- 10に示すように, 変動傾向及 び変動幅を比較的良好に再現することができた. 井戸深 度が約100mで深い観測井NNo.1では，降雨に対して緩やか に増減する地下水位変化を, 井戸深度が $10 \sim 20 \mathrm{~m}$ と比較的 浅い観測井No. 2, №.3では，降雨に対して鋭敏に反応する 地位水位の特徽が計算結果に表れている.
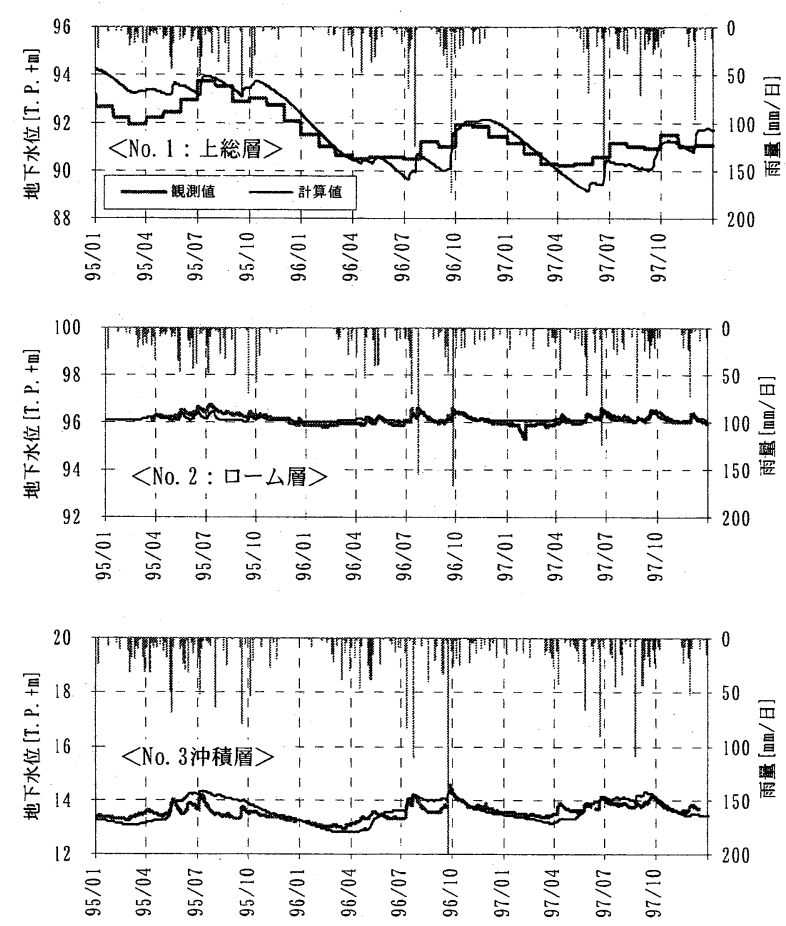

図-10 地下水位の再現結果

\section{4. おわりに}

中村ほかによって開発され, 都市内小河川である海老 川流域で検証されたグリッド型水循環系解析モデルを多 摩川流域に適用した。

解析では, 河川流量及び地下水位時系列の観測值に対 して概ね良好な再現結果を得たが, 河川流量の再現結果 から流域面積に森林域の占める割合が高い秋川流域で表 層土壤内の流出機構及び蒸発散のモデル化において改善 すべき点が残った. また, 今回検証の対象とした観測井で の計算結果の再現性は比較的良好であったが, さらに多 くの観測井における地下水位変動や被圧地下水位の平面 分布に関する検証を行う必要があると考えられる.

河川流量及び地下水位に関する検証事例を重ねてモデ ルの信頼性を高めるとともに, 本モデルに分布型污濁負 荷流出モデルを用いた河川水質の評価・予測機能を拡張 し, 流域内の水之污濁負荷の流れを合わせて評価可能な 水循環系解析モデルを構築することが今後の課題である.

謝辞 : 本検討にあたり種々のご指導を頂いた東京大学生 産技術研究所 虫朋功臣教授，香川大学 河原能久教授，日 本工営株式会社 斎藤庸氏, 石原千晶氏に深甚なる感謝の 意を表します.

\section{参考文献}

1)鶴見川とその流域の再生〜鶴見川流域水マスタープラ ン策定に向けた提言〜,財団法人 リバーフロント整備 センター,2002.

2)柳瀬川流域水循環マスタープラン 中間取りまとめ,柳 瀬川水循環マスタープラン事務局,2002.

3)中村茂・ 中嶋規行 - 忌部正博 - Srikantha Herath: グ リッド型水循環系解析モデルの開発 海老川流域を対 象として，水工学論文集,第45巻,pp.103-108,2000.

4) Ni G., Musiake K., Herath S.: A distributed catchment model and its application to simulate urbanization effect, Proc. 9th APD-IAHR, pp.254-261, 1994.

5) Herath, S., Musiake, K., and Hironaka S.: Development and Application of a GIS based Distributed Catchment Model for Urban Areas, Proc. 7th International Conference on Urban Storm Drainage, 1695 - 1700, 1996.

6) Herath, S., Jha, R., and Musiake, K.: Application of IISDHM in Northern Chao Phraya, Thailand, The Third Intl. Study Conference on GEWEX in Asia and GAME, GAME International Science Panel, pp.125-133.,1997.

7) Jha, R., Herath, S. and Musiake, K.: Development of IIS Distributed Hydrological Model (IISDHM) and its Application in Chao Phraya river basin: Annual Journal of Hydraulic Engineering, JSCE, pp. 227-232., 1997.

8)高木康行,中村茂,Srikantha Herath,羽田野环磨 : グリッ ド型水循環系解析における不浸透面積率の決定手法に ついて,第56回年次学術講演会概要集第2部門, pp.250251, 2001.

9)Harvercamp, R, Vauclin, M., Touma, J., Wierenga, P.J., Vauchad, G.: A comparison of numerical simulation models for one-dimensional infiltration, Soil Sci. Soc. Am. J., Vol 41, pp.285-293, 1977.

10)Mualem, Y.: Hydraulic conductivity of unsaturated porous media: Generalized macroscopic approach, Water Resources Research, Vol.14, No.2, pp.325-334, 1978.

11)村井宏,岩崎勇作: 林地の水および土袞保全機能に関 する研究（第 1 報），林試研報274,1975.

12）「都市小流域における雨水浸透,流出機構の定量的解 明」研究会 : 都市域における水循環系の定量化手法 ？ 水循環系の再生に向けて-社団法人 雨水貯留浸透 技術協会,2000.

13)橋本建, 長谷川正 : 土地利用を評価する流出モデル, 土木技術資料, 19-5, pp.13, 1977.

14)羽田野琢磨,中村茂,高木康行,Srikantha Herath : グリッ ド型水循環系解析における落水線の作成方法について, 第56回年次学術講演会概要集第2部門, pp.249-250, 2001.

15)McDonald, Harbaugh : A modular three-dimensional finitedifference ground-water flow model; Tech, Water-Resources Inv., Bk. 6, Chap. A1; 1988.

（2002. 9. 30受付） 